\title{
Spontaneous rupture of pregnancy luteoma
}

\section{Pınar Yalçın Bahat*, Berna Aslan Çetin, Gökçe Turan}

Istanbul Kanuni Sultan Suleyman Training and Research Hospital, Istanbul, Turkey

Received: 13 February 2017

Accepted: 07 March 2017

\section{* Correspondence:}

Dr. Pınar Yalçın Bahat,

E-mail: dr_pinaryalcin@ hotmail.com

Copyright: () the author(s), publisher and licensee Medip Academy. This is an open-access article distributed under the terms of the Creative Commons Attribution Non-Commercial License, which permits unrestricted non-commercial use, distribution, and reproduction in any medium, provided the original work is properly cited.

\begin{abstract}
Luteoma is a rare condition in pregnancy. In this article, we aimed to present a rare case of pregnancy luteoma detected during cesarean section and pathologically in the context of literature information.
\end{abstract}

Keywords: Luteoma, Pregnancy, Virilization

\section{INTRODUCTION}

Pregnancy luteoma is a different neoplastic lesion characterized by solid proliferation of ovarian luteinizing cells. Benign is one of the most common causes of maternal virilization. ${ }^{1,2}$ It is thought to be a consequence of excessive hCG (human chorionic gonadotropin) stimulation from theca-lutein cells. It may be unilateral or bilateral, $1 / 3^{\text {rd }}$ is bilateral. It is often asymptomatic. ${ }^{3}$ The most common clinical signs are maternal virilization, hemorrhage, or acute abdomen which can be seen as a torsion secondary. ${ }^{4,5}$ Ovarian growth is usually recognized incidentally during cesarean or postpartum tube ligation.

\section{CASE REPORT}

A 24-year-old G2P1 patient with a previous caesarean section with 31 weeks and 6 days of twin pregnancy was referred to our clinic for pain and acute abdomen. After the examination and ultrasonography the patient was found to have a cervical span of $6 \mathrm{~cm}$ and a dilatation of up to $70 \%$. In the Douglas cavity and under the liver, free fluid was seen and the patient received an emergency cesarean section. During the operation, $700 \mathrm{cc}$ of hemorrhagic fluid was observed in the abdomen. Healthy male infants with $1700 \mathrm{gr}$ and 1790 gr APGARs 7/9 were born. A spontaneous rupture area of approximately $3 \mathrm{~cm}$ on the right ovary and an increase in both ovaries were noted. The left ovary was approximately $7 \mathrm{~cm}$ and the ruptured right over was approximately $8 \mathrm{~cm}$ (Figure 1) Both over-surfaces were fragile and irregular.

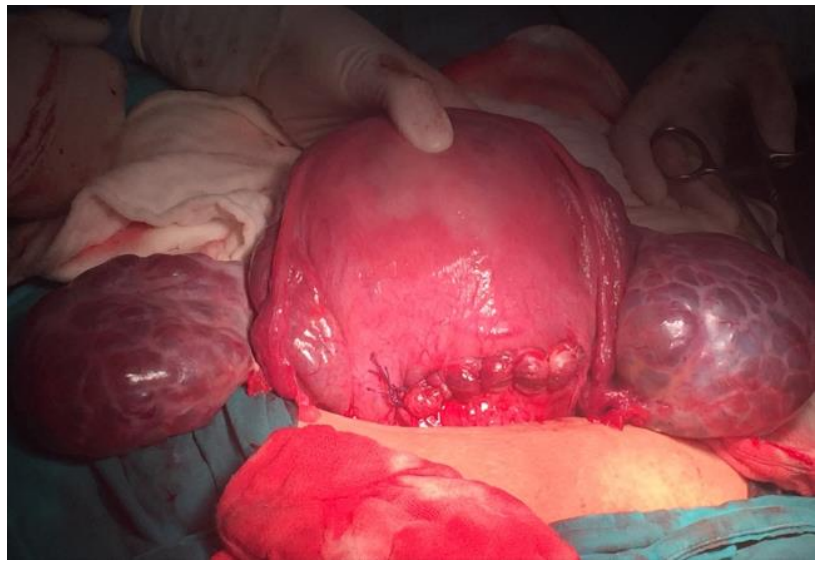

Figure 1: The appearance of both ovaries.

After the Kerr incision in uterus was sutured, the oncology consultation was requested. Biopsy materials were taken from the left ovary, where the size of ovary has increased and the right ovary rupture area (Figure 2) of the patient who was thought for pregnancy luteoma. And biopsy materials were sutured. Considering the increased sensitivity of the ovaries, the drain was not inserted. At the end of the operation, an increase in hair growth was observed in the body examination of the patient and it was learned that there was a 3-month 
treatment history due to hormonal dysfunction prior to pregnancy. On the third day of post-op treatment, the patient was discharged with cure due to the stabilization of the vitals and the usual signs of the abdominal findings.

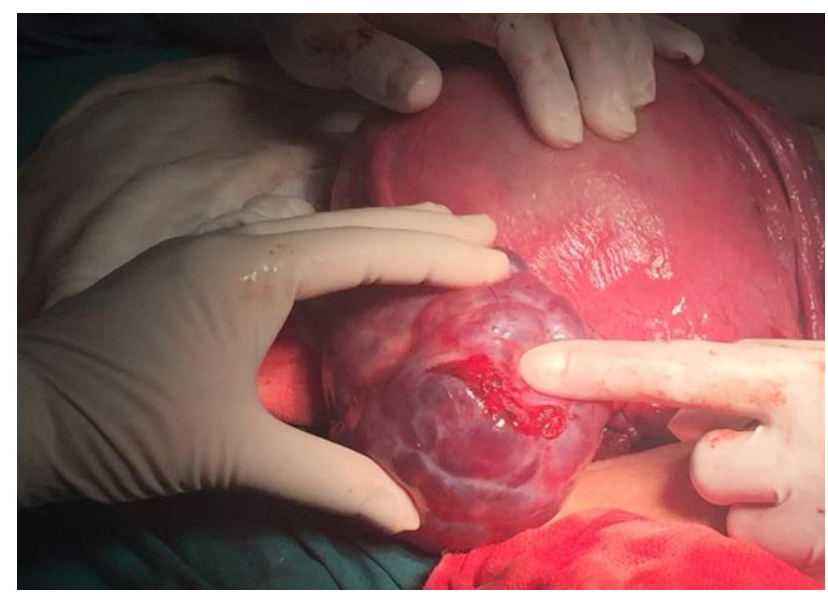

Figure 2: Right ovary spontaneous rupture area.

Tissue microscopy was compatible with pregnancy luteoma and the patient was called to the clinic for follow-up..$^{6-7}$ On the post-op 40th day, in the transvaginal ultrasonography, patient's bilateral ovary sizes were observed usual, and tumor markers (ca125, ca15.3, ca19.9), hCG (human chorionic gonadotropin) and testosterone values were normal, too.

\section{DISCUSSION}

The luteoma, first described by Sternberg in 1963, is a very rare benign ovarian tumor with postpartum regression that develops during the later gestational weeks. Pregnancy luteoma causes virilization findings on more than $50 \%$ of female fetuses. ${ }^{8}$ Male fetuses do not have fetal signs. While virilization findings were not observed in our patient, fetal anomaly was not observed because both fetuses were male. $1 / 3^{\text {rd }}$ of the cases are bilaterals, just as in our case. Most patients are asymptomatic and incidentally detected during cesarean section. Our case was applied due to the ovarian ruptured acute abdomen and hemorrhagic fluid was detected during operation. Ovarian size can reach up to $20 \mathrm{~cm}$ in the pregnancy luteoma, ovarian surface is seen irregular and fragile. In our case, the ovary size was increased up to $8 \mathrm{~cm}$, the ovary surface was fragile and irregular both in the ruptured right ovary and in the not ruptured left ovary. During pregnancy, if ascending ovary size compatible with luteoma are detected, in asymptomatic cases, the correct approach will be postpartum ultrasonographic follow-up to avoid unnecessary surgical intervention and to wait for spontaneous regression of ovary sizes. ${ }^{9}$ In cases with an acute abdomen as in our case or incidentally detected during a cesarean section, biopsy and correcting the ovary rupture or torsion table leading to the present acute abdomen, will be an adequate approach. It should be considered that one-third of the cases are bilateral and biopsy should be done from the opposite ovary as we did in our case.

As a result, pregnancy luteoma is a very rare postpartum spontaneous regressive condition that occurs as a physiologic response of ovaries for HCG during pregnancy. Pregnancy luteoma should be considered if there is a certain diagnosis as increased ovary size during pregnancy.

Funding: No funding sources

Conflict of interest: None declared

Ethical approval: Not required

\section{REFERENCES}

1. Sternberg WH, Barclay DL. Luteoma of pregnancy. Am J Obstet Gynecol. 1966;95(2):165-84.

2. Clement PB. Tumor-like lesions of the ovary associated with pregnancy. Int $\mathrm{J}$ Gynecol Pathol. 1993;12(2):657-62.

3. Scully RE, Young RH, Clement PB. Tumor-like lesions. In: Gonads M, Tube F, Ligament B, editors. Tumors of the ovary. Washington, DC. 1996:422-4.

4. Irving JA, Clement PB. Nonneoplastic lesions of the ovary. In: Kurman RJ, Ellenson LH, Ronnett BM, editor. Blaustein's pathology of the female genital tract. 6th ed. New York: Springer Science+Business Media. 2011:580-624.

5. Kerber IJ, Bell JS, Camacho AM, Fish SA. Luteoma of pregnancy: recurrent or persistent? South Med J. 1969;62(11):1343-8.

6. Çelik Ö. Gebelik luteoması. Turgut Özal Tıp Merkezi Dergisi 2000;7(3):274-5.

7. Longacre TA, Gilks CB. Nonneoplastic lesions of the ovary. In: Goldblum JR, editor. Gynecologic pathology. 1st ed. Churchill Livingstone Elsevier. 2009:367-91.

8. Masarie K, Katz V, Balderston K. Pregnancy luteomas: clinical presentations and management strategies. Obstet Gynecol Surv. 2010;65(9):575-82.

9. Yalçın ÖT, Özalp S, Yıldırım A, Şener T, Cevrioğlu AS. Rüptüre luteoma nedeniyle bilateral ooferektomi uygulanan 8 haftalık bir gebelikte yaklaşım. Perinatoloji Dergisi. 1996;4(4):212-4.

Cite this article as: Bahat PY, Çetin BA, Turan G. Spontaneous rupture of pregnancy luteoma. Int J Reprod Contracept Obstet Gynecol 2017;6:1689-90. 